\title{
The Levels of Asymmetric Dimethylarginine in Patients with Isolated Coronary Artery Ectasia
}

\author{
İsmail Erden ${ }^{1}$, Emine Çakcak Erden², Serhat Bahadır Sözen¹, Osman Kayapınar¹,
} Sabri Onur Çağlar ${ }^{1}$, Cengiz Bașar ${ }^{1}$

${ }^{1}$ Düzce University, School of Medicine, Department of Cardiology, Düzce, Turkey

${ }^{2}$ Adatip Hospital Department of Cardiology, Sakarya, Turkey

Eur J Gen Med 2010;7(4):404-409

Received: 27.01.2010

Accepted: 08.04.2010
Correspondence: Dr. İsmail Erden Duzce University Düzce Medical School Department of Cardiology 81620 Konuralp, Düzce, Turkey

Tel: 03805421392-5766

Fax: 903805421387, GSM: 05323075599

E-mail: iserdemus@yahoo.com

\begin{abstract}
Aim: Although underlying mechanisms of coronary artery ectasia (CAE) are clearly unknown, endothelial dysfunction may be responsible for the coronary ectasia. Asymmetric dimethylarginine (ADMA) is the principal endogenous inhibitor of nitric oxide synthase and elevated levels of ADMA is considered to be a marker of endothelial dysfunction and increased risk of cardiovascular disease. Accordingly, we investigated serum ADMA levels in patients with CAE in comparison with participants having normal coronary artery.
\end{abstract}

Method: This study consisted of 41 consecutive patients with angiographically proven normal coronary arteries with CAE and 48 controls with normal coronary arteries without coronary artery ectasia undergoing cardiac catheterization. Serum levels of ADMA were measured by Enzyme Linked Immunosorbent Assay.

Result: Serum level of ADMA was significantly higher in CAE patients compared with controls $(1.9 \pm 0.9 \mu \mathrm{mol} / \mathrm{l}$ vs. $1.1 \pm 0.7 \mu \mathrm{mol} / \mathrm{l}$, respectively, $p=0.01)$. Serum ADMA levels was an independent predictor for CAE (OR=1.486 [95\% confidence interval $(C I): 0.978-2.054 ; p=0.03]$ ). ADMA levels correlated with diffuse ectasia $(p=0.04)$.

Conclusion: Our findings provide evidence to support the hypothesis that endothelial dysfunction may be an important factor in the pathogenesis of $C A E$.

Key words: Coronary artery, ectasia, asymmetric dimethylarginine 


\section{İole Koroner Arter Ektazili Hastalarda Asymmetric Dimethylarginine Seviyeleri}

Amaç: Koroner arter ektazinin (KAE) temelinde yatan mekanizma tam alorak bilinmemesine rağmen, endotel disfonksiyonu koroner ektazide rol oynuyor olabilir. Asymmetric dimethylarginine (ADMA) nitrik oksit sentazın endojen inhibitörüdür ve artmıș ADMA seviyelerinin endotel disfonksiyonu ve artmıș kardiyovasküler hastalık riskiyle ilișkili olduğu düșünülmektedir. Bu çalıșmada, normal koroner arterlere sahip kișilerle koroner arter ektazisi olan hastalarda serum ADMA düzeylerini araștırıp karșılaștırdık.

Metod: Çalıșmaya anjografik olarak normal koroner arterlere sahip olduğu görülmüș 41 koroner arter ektazili hasta ile normal koroner arterlere sahip ektazisi olmayan 48 hasta dahil edilmiștir. Serum ADMA seviyeleri ELISA yöntemiyle ölçülmüștür.

Bulgular: Kontrol grubuyla kıyaslandığında koroner arter ektazisi olan hastalarda serum ADMA düzeyleri anlamlı olarak yüksek saptanmıștır. $(1.9 \pm 0.9 \mu \mathrm{mol} / \mathrm{l}$ vs. $1.1 \pm 0.7 \mu \mathrm{mol} / \mathrm{l}, p=0.01)$ Serum ADMA düzeyleri koroner arter ektazisi için bağımsız bir öngördürücü belirteçtir. $(O R=1.486$ [95\% (Cl): 0.978-2.054; $p=0.03])$. Adma seviyeleri diffüz ektaziyle ilișkilidir. $(p=0.04)$

Sonuç: Saptadığımız bulgular, endotelyal disfonksiyonun KAE patogenezinde önemli bir faktör olduğunu desteklemektedir. Anahtar kelimeler: Koroner arter ektazisi, asimetrik dimetil arjinin

\section{INTRODUCTION}

Coronary artery ectasia (CAE) has been defined as localized or diffuse dilation of the coronary arteries exceeding the 1.5 fold of normal adjacent segment in coronary angiography $(1,2)$. Prevalence of CAE appears to rise in recent years (3). Although coronary artery disease (CAD) is supposed to be responsible for more than $50 \%$ of coronary ectasia, the precise pathology of CAE is not clearly understood. The frequent coexistence of CAE with CAD and histopathological findings resembling those of atherosclerosis have led to the conclusion that the mechanism underlying the pathogenesis of CAE is a variant of atherosclerosis (4).

The main coronary angiographic characteristics of CAE are impaired coronary blood flow, delayed antegrade coronary dye filling, segmental back flow phenomenon (milking phenomenon) and stasis with local deposition of dye in dilated coronary segments (5). Recent reports have implicated aneurysmal coronary arteries seem to have impaired flow velocities, flow reserve and microvascular flow dynamics, which may lead to inducible myocardial ischemia even in the absence of epicardial obstructive disease $(6,7)$.

In the literature, the phenomenon of slow coronary flow (SCF) is well known for coronary artery ectasia. Severel attempts have been made by using TIMI [Thrombolysis in Myocardial Infarction] frame count method (CTFC) to determine whether SCF is evident in CAE. It has been speculated that slow flow is aggravated with increasing severity of ectasia involvement. It has been suggested that a higher CTFC might reflect disordered resistance vessel function $(8,9)$. Altough a lot of reports have implicated endothelial dysfunction as an underlying pathophysiological mechanism of SCF phenomenon. There is no clear information in the literature about the parameters that reveal the role of endothelial dysfunction in pathogenesis of CAE.

Asymmetric dimethylarginine (ADMA) is an endogenous inhibitor of nitric oxide (NO) synthesis (10). The nitric oxide produced by the endothelium under the action of endothelial nitric oxide synthase has important antiatherogenic functions. Its reduced bioavailabilty is the beginning of the atherosclerotic process. Recently, elevated serum levels of ADMA have been demonstrated to be associated with cardiovascular disease and many of the risk factors related with endothelial dysfunction such as hypercholesterolemia, hypertension, smoking and diabetes (11). Therefore, elevated serum concentrations of ADMA have been considered as an indicator of endothelial dysfunction and a risk factor for cardiovascular disease $(12,13)$.

In this study, we tested the hypothesis that endothelial dysfunction may be present in patients with CAE. Therefore, we investigated serum ADMA levels in patients with and without CAE.

\section{MATERIALS AND METHODS}

Forty-one consecutive patients with angiographically proven normal coronary arteries and CAE (28 men, 13 women, mean age: $54.4 \pm 10.5$ years) and forty-eight sex and age matched control participants with angiographically proven normal coronary arteries but without associated CAE (27 men, 21 women, mean age: $51.1 \pm 14.1$ years) were included in the study. All study participants referred to coronary angiography due to the presence of angina, angina-like chest pain, positive or equivocal results of stress test for myocardial ischemia. Each 
Table 1. Baseline clinical characteristics of the study population

\begin{tabular}{llll}
\hline & CAE (n: 41$)$ & Control (n: 48) & $p$ value \\
\hline Age (years) & $54.4 \pm 10.5$ & $51.1 \pm 14.10 .187$ & \\
Female patients $n(\%)$ & $13(31.7)$ & $21(43.7)$ & 0.279 \\
Hypertension $n(\%)$ & $21(51.2)$ & $17(35.4)$ & 0.196 \\
Diabetes Mellitus $n(\%)$ & $6(14.6)$ & $11(22.9)$ & 0.420 \\
Smoking $n(\%)$ & $24(58.5)$ & $20(41.6)$ & 0.138 \\
Familiy History $n(\%)$ & $7(17.0)$ & $7(14.5)$ & 0.777 \\
BMl (kglm2) & $30.1 \pm 6.3$ & $29.2 \pm 5.9$ & 0.343 \\
GFR (mllmin) & $102.6 \pm 46.8$ & $118.4 \pm 37.6$ & 0.146 \\
Total cholesterol $(\mathrm{mg} / \mathrm{dL})$ & $185.8 \pm 31.6$ & $179 \pm 35.8$ & 0.462 \\
LDL cholesterol $(\mathrm{mg} / \mathrm{dl})$ & $112 \pm 36.6$ & $106 \pm 34.7$ & 0.435 \\
HDL cholesterol $(\mathrm{mg} / \mathrm{dl})$ & $40.6 \pm 11.9$ & $44 \pm 13.4$ & 0.352 \\
Triglyceride $(\mathrm{mgldl})$ & $164 \pm 105.6$ & $151 \pm 91.8$ & 0.212 \\
\hline
\end{tabular}

BMI, body mass index; BP, blood pressure; GFR, glomerular filtration rate; HDL, high-density lipoprotein; LAD, LDL, low-density lipoprotein.

participant in both groups underwent physical and laboratory examinations and were questioned about the risk factors for coronary artery disease. Patients with coronary artery disease including obstructive lesions, unstable angina, valvular heart disease, any form of cardiomyopathies, left ventricular wall motion abnormality assessed by left ventriculography, documented arrhythmia, renal and hepatic dysfunction, or any history of systemic disease were excluded from the study. Renal function was evaluated by estimating glomerular filtration rate (GFR) according to the Cockcroft formula:

GFR $(\mathrm{ml} \backslash \mathrm{min})=(140-$ age $) \times$ bodyweight $(\mathrm{kg}) /[72 \mathrm{x}$ serumcreatinine $(\mathrm{mgldl})]$. For women, a factor of 0.85 was applied (14).

No significant difference was present between the two groups regarding the use of acetylsalicylic acid, beta blockers, nitrates, calcium-channel blockers, and statins. All patients and controls had given informed consent and the study protocol was approved by our institutional investigational review board.

Coronary angiography was performed by femoral approach using the standard Judkins technique. Coronary diameters were measured by computerized quantitative angiography in a biplane mode. CAE was defined as an arterial segment with a diameter of $>1.5$ times the diameter of the adjacent normal coronary artery (15). If no adjacent normal segment could be identified, the mean diameters of the coronary segments in a control group without coronary disease served as normal values.

The severity of CAE was determined that Markis et al. (16) as they define, the distribution of CAE was classified by both observers in consensus in each patient into four distinct types: type I, diffuse ectasia of two or three vessels; type II, diffuse disease in one vessel and localized disease in another vessel; type III, diffuse ectasia of one vessel only; type IV, localized or segmental ectasia.

Venous blood samples were collected following 12 hours of overnight fasting and the serum were separated by centrifugation at $2500 \mathrm{rpm}$. Glucose, total cholesterol, high-density lipoprotein (HDL) cholesterol, low-density lipoprotein (LDL) cholesterol, and triglyceride were measured by enzymatic methods in a Arcthitect C 800 device. Serum samples separated for ADMA measurement were stored at $-20{ }^{\circ} \mathrm{C}$ for a short period of time, and the tests were performed by ELISA (Enzyme Linked Immunosorbent Assay) method using Immun Diagnostica AG kits (Cat. No: K7814-090204). The analytic sensitivity of the test was $0.05 \mu \mathrm{mol} / \mathrm{l}$, and the intra-assay variation coefficient (CV\%) for the two separate concentrations were 7.5 (mean value: $0.81, S D: 0.06, n=36$ ) and 4.5 (mean value: $1.76, S D: 0.08, n=36$ ).

\section{Statistical analysis}

All values are given as mean \pm standard deviation. Statistical Package for Social Sciences software (SPSS 10.0, Chicago, IL, USA) was used for comparisons of demographic, angiographic and clinical variables. Unpaired Student's t test was used for group comparisons. Categorical data were compared with the chisquare test. In order to understand whether ADMA level is an independent determinant for CAE, logistic regression analysis was performed. The covariates considered were ADMA level, sex, age, hypertension, diabetes mellitus, hyperlipidemia, family history, cigarette smoking. Statistical significance was defined as $p<0.05$. 


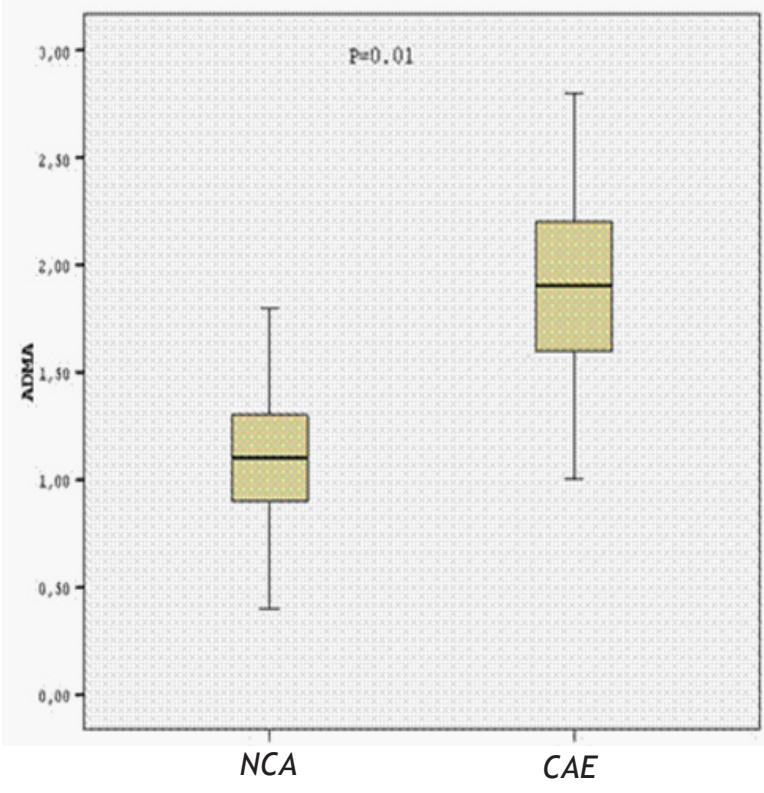

Figure 1. Comparison of serum ADMA concentrations in patients with CAE and normal coronary artery $(P=0.01)$. ADMA, asymmetric dimethylarginine; $C A E$, coronary artery ectasia; NCA, normal coronary artery.

\section{RESULTS}

The baseline demographic, clinical and angiographic characteristics of the patients with CAE and normal coronary flow are presented in Table 1 . The groups did not differ in terms of age, sex, body mass index (all $\mathrm{p}>0.05$ ). In addition, in patients with CAE, the risk factors for coronary artery disease such as hypertension, hyperlipidemia, diabetes mellitus, cigarette smoking and family history did not significantly differ from patients with normal coronary artery (all $p>0.05$ ). In addition, the groups were similar in terms of serum levels of total cholesterol, low-density lipoprotein cholesterol, high-density lipoprotein cholesterol, triglyceride and GFR (all $p>0.05$ ).

CAE was frequently located in the right coronary artery (71\%), followed by in left anterior descending artery (59\%), and circumflex artery (39\%) territories. According to the Markis classification, 16 type I was present in $17.0 \%$ of the patients $(7 / 41)$, type II in $34.1 \%(14 / 41)$, type III in $24.3 \%$ (10/41), and type IV in $24.3 .5 \%$ (10/41).

Serum ADMA concentrations in patients with CAE were found to be significantly higher $(1.9 \pm 0.9 \mu \mathrm{mol} / \mathrm{l} \mathrm{vs}$. $1.1 \pm 0.7 \mu \mathrm{mol} / \mathrm{l}, \mathrm{p}=0.01)$ than those of control participants (Figure-1). In order to understand whether ADMA level is an independent determinant for CAE, logistic regression analysis was performed. The covariates considered were age, sex, hypertension, diabetes mellitus, hyperlipidemia, family history and cigarette smoking. The analysis showed that ADMA level is an independent determinant for CAE besides male sex, hypertension and cigarette smoking [OR= 1.486 [95\% confidence interval $(\mathrm{Cl})$ : 0.978-2.054; $\mathrm{P}=0.03$ ]. In subgroup analyses, ADMA level was higher in patients with widespread involvement with ectasia (Markis Tip1+Tip2) compared with mild involvement (Markis Tip3+Tip4). Respectively $2.1 \pm 0.6$ vs. $1.6 \pm 0.7 \mu \mathrm{mol} / \mathrm{l}, \mathrm{p}=0.04$.

\section{DISCUSSION}

This study showed that serum levels of ADMA was significantly higher in CAE patients compared with controls. Furthermore, ADMA level correlated with the severity of CAE.

CAE is defined as localized or diffuse dilation of the coronary arteries that frequently coexists with atherosclerotic coronary artery stenosis. Although it has been suggested that ectasia is commonly a variant of obstructive CAD, its pathogenesis remains poorly understood $(1,2,17)$. Coronary flow in aneurysmal segments is impaired even in the absence of obstructive disease. The mechanism of myocardial ischemia in isolated diffuse CAE without coexisting coronary artery stenosis is unknown. There is evidence suggesting that endothelial dysfunction contributes to micro-vascular dysfunction (18). Although the precise mechanism of endothelial dysfunction is not clear in CAE; changes in flow properties in the dilated segments with subsequent alterations in blood viscosity, activation of the coagulation system and distal coronary embolization of material originated in the ectatic segment may explain the possible underlying ischemia $(4,5)$. Papadakis et al., (6) 39 reviewed the angiograms of 173 patients with ectasia, and found lower coronary flow velocities (by the TIMI [Thrombolysis in Myocardial Infarction] frame count method) in patients with isolated coronary ectasia compared with patients with obstructive CAD. Similarly, in a study by Gulec et al, (7) $46 \%$ of the 94 ectatic coronaries in 45 patients had impaired epicardial flow (TIMI 2 or less). In addition, the microvascular perfusion (as 
assessed by the myocardial blush grade method) was impaired not only in those with abnormal TIMI flow, but also in $45 \%$ of ectatic coronaries with normal TIMI 3 epicardial flow. These 2 studies suggest that ectatic coronaries, by virtue of their increased diameter, have not only impaired coronary flow, but also impairment of the microcirculation. Eventually, aneurysmal coronary arteries seem to have impaired flow velocities, flow reserve and microvascular flow dynamics, which may lead to inducible myocardial ischemia even in the absence of epicardial obstructive disease.

In the literature, the phenomenon of slow coronary flow is well known for coronary artery ectasia $(8,9)$. Severel attempts have been made by using CTFC to determine whether SCF is evident in CAE. It has been speculated that slow flow is aggravated with increasing severity of ectasia involvement. It has been suggested that a higher CTFC might reflect disordered resistance vessel function. Recent reports have implicated endothelial dysfunction as an underlying pathophysiological mechanism of SCF phenomenon. Accordingly, it has been concluded that abnormal slow flow pattern in coronary arteries may lead to diffuse atherosclerotic disease by damaging endothelium without creating an angiographically visible coronary lesion and SCF could be an early manifestation of diffuse atherosclerosis involving both the microvascular system and epicardial coronary arteries. These observations suggest that a pathophysiologically relevant interaction exists between SCF phenomenon and endothelial dysfunction (19-21).

Endothelial dysfunction represents one of the earliest events in the pathogenesis of cardiovascular disease preceding the documentation of atherosclerotic plaques by angiography or ultrasound (22). Over the last decade, evidence has accumulated from clinical and experimental studies for a close association of elevated serum concentrations of ADMA and vascular endothelial dysfunction and hence, ADMA was considered as an indicator of early atherosclerosis. An accumulating body of evidence exists that ADMA reduces vascular compliance, increases vascular resistance, and limits blood flow by inhibiting NO synthesis (23). The major findings of this study that the patients with CAE have higher serum concentrations of ADMA further strengthen the concept that vascular endothelial function is impaired in patients with CAE.

The CAE phenomenon is an important clinical condition because the patients with CAE may present with chest pain most often requiring urgent admission to coronary care unit, have ST segment depression in treadmill tests or regional defects in myocardial scintigraphy (24). Kruger et al (8) studied 42 patients with isolated bilateral coronary ectasia and aneurysms for evidence of inducible myocardial ischemia. They used exercise stress testing and coronary sinus lactate measurements during atrial pacing. Their study demonstrated evidence of exercise-induced myocardial ischemia that was more pronounced in patients with bilateral large CAE defined as $>2$ times the diameter of the reference segment. These patients not only had angiographic evidence of slow flow and impaired myocardial perfusion, but also increased coronary sinus lactate production. Patients with bilateral ectasias defined as 1.5-2.0 times the diameter of the normal reference were also found to have inducible ischemia, although not as severe as in those with large bilateral aneurysms.

Although this study was not designed to investigate the mechanism by which ADMA contributes to CAE, it may be concluded that, by impairing coronary flow, elevated serum concentrations of ADMA may be responsible for the myocardial ischemic symptoms and the positive results of stress test for myocardial ischemia in patients with CAE. Thus, it may be suggested that ADMA reducing therapies such as angiotensin converting- enzyme inhibitors and receptor antagonists or rosiglitazone may be helpful in the treatment of patients by improving endothelial dysfunction $(25,26)$. To provide symptomatic relief and improve the objective findings of myocardial ischemia, much interest should be focused on the exact mechanisms and the therapeutic approaches of CAE.

\section{Study limitations}

This study has some limitations. In addition to the relatively small number of the patients, the study is limited by the definition of the normal coronary arteries by coronary angiography. The visual angiographic evaluation of coronary arteries may not represent the true extent of atherosclerosis and may lead to underestimation of the presence of coronary artery disease. It was, however, impossible to perform intravascular ultrasound, which is the most sensitive technique for detecting atherosclerotic plaques in patients with angiographically normal coronary arteries. 27 Another limitation of this study is the lack of a functional assessment of endothelial function such as coronary flow reserve measurement that would add further support to the contribution of 
endothelial dysfunction to the development of CAE.

In conclusion, endothelial function determined by the measurement of serum ADMA levels was impaired in patients with coronary artery ectasia compared to those with normal coronary arteries. These findings suggest that endothelial dysfunction may play an important role in the etiology of CAE and therapeutic strategies targeting endothelial dysfunction may be useful in the management of patients with CAE.

\section{REFERENCES}

1. Swaye PS, Fisher LD, Litwin P, et al. Aneurysmal coronary artery disease. Circulation 1983;67:134-8.

2. H. L. Falsetti, R. J. Carroll, Swope RD, Chen JC. Coronary artery aneurysm. Chest 1976;69:630-6.

3. Giannoglou GD, Antoniadis AP, Chatzizisis YS, Damvopoulou $E$, Parcharidis GE, Louridas GE. Prevalence of ectasia in human coronary arteries in patients in Northern Greece referred for coronary angiography. The American Journal of Cardiology 2006;98:314-8.

4. Chrissoheris MP, Donohue TJ, Young RSK, Ghantous A. Coronary Artery Aneurysms. Cardiology in Review 2008; $16: 116-23$

5. Yetkin E, Waltenberger J. Novel insights into an old controversy: Is coronary artery ectasia a variant of coronary atherosclerosis? Clin Res Cardiol 2007;96:331-9.

6. Papadakis MC, Manginas A, Cotileas P, Demopoulos $V$, Voudris V, Pavlides G, Foussas SG, Cokkinos DV. Documentation of Slow Coronary Flow by the TIMI Frame Count in Patients With Coronary Ectasia. Am J Card 2001;88:1030-2.

7. Gulec S, Atmaca Y, Kilickap M, Akyürek O, Aras O, Oral D. Angiographic assessment of myocardial perfusion in patients with isolated coronary artery ectasia. Am J Card 2003;91:996-8.

8. Kruger D, Stierle U, Herrmann $G$, et al. Exercise-induced myocardial ischemia in isolated coronary artery ectasias and aneurysms ("Dilated Coronaropathy"). J Am Coll Cardiol 1999;34:1461-70.

9. Senen $K$, Yetkin $E$, Turhan $H$, et al. Increased thrombolysis in myocardial infartion frame counts in patients with isolated coronary artery ectasia. Heart Vessels 2004;19:23-6.

10. Vallance $P$, Leone A, Calver A, Collier J, Moncada S. Endogenous dimethylarginine as an inhibitor of nitric oxide synthesis. J Cardiovasc Pharmacol 1992;20(suppl 12):60-2.

11. Landim MBP, Casella Filho A, Chagas ACP. Asymmetric dimethylarginine (ADMA) and endothelial dysfunction: implications for atherogenesis. Clinics 2009;64(5):471-8.
12. Miyazaki $H$, Matsuoka $H$, Cooke JP, et al. Endogenous nitric oxide synthase inhibitor: a novel marker of atherosclerosis. Circulation 1999;99:1141-6.

13. Boger RH. The emerging role of asymmetric dimethylarginine as a novel cardiovascular risk factor. Cardiovasc Res 2003;59:824-33.

14. Cockcroft DW, Gault MH. Prediction of creatinine clearance from serum creatinine. Nephron 1976;16:31-41.

15. Hartnell GG, Parnell BM, Pridie RB. Coronary artery ectasia-its prevalence and clinical significance in 4993 patients. Br Heart J 1985;54:392-5.

16. Markis JE, Joffe CD, Cohn PF, Feen DJ, Herman MV, Gorlin $R$. Clinical significance of coronary arterial ectasia. Am J Cardiol 1976; 37: 217-22.

17. Swanton RH, Lea Thomas M, Coltarte DJ, Jenkins BS, Webb-Peploe MM, Williams BT. Coronary artery ectasia, a variant of occlusive coronary arteriosclerosis. Br Heart J 1978;40:393-400.

18. Landmesser $U$, Drexler $H$. The clinical significance of endothelial dysfunction. Curr Opin Cardiol 2005;20:547-51.

19. Mangieri E, Macchiarelli G, Ciavolella M, et al. Slow coronary flow: clinical and histopathological features in patients with otherwise normal epicardial coronary arteries. Cathet Cardiovasc Diagn 1996;37:375-81.

20. Cin VG, Pekdemir H, Camsar A, et al. Diffuse intimal thickening of coronary arteries in slow coronary flow. Jpn Heart J 2003;44:907-19

21. Sezgin AT, Sigirci A, Barutcu I, Topal E, Sezgin N, Ozdemir $R$, et al. Vascular endothelial function in patients with slow coronary flow. Coron Artery Dis 2003;14:155-61.

22. Vallance $P$. Importance of asymmetrical dimethylarginine in cardiovascular risk. Lancet 2001;358:2096-7

23. Cooke JP. Asymmetrical dimethylarginine: the Uber marker? Circulation 2004;109:1813-8.

24. Sayin $T$, Doven $O$, Berkalp $B$, Akyürek $O$, Gulec $S$, Oral $D$. Exercise induced myocardial ischemia in patients with coronary artery ectasia without obstructive coronary artery disease. Int J Cardiol 2001;78:143-9

25. Delles C, Schneider MP, John S, Gekle M, Schmieder RE. Angiotensin converting enzyme inhibition and angiotensin II AT1-receptor blockade reduce the levels of asymmetrical $N(G), N(G)$-dimethylarginine in human essential hypertension. Am J Hypertens 2002;15:590-3.

26. Stuhlinger MC, Abbasi F, Chu JW, et al. Relationship between insulin resistance and an endogenous nitric oxide synthase inhibitor. JAMA 2002;287:1420-6.

27. Mintz GS, Painter JA, Pichard AD, K, et al. Atherosclerosis in angiographically 'normal' coronary artery reference segments: an intravascular ultrasound study with clinical correlations. J Am Coll Cardiol 1995; 5:1479-85. 